JOM, Vol. 71, No. 6, 2019

https://doi.org/10.1007/s11837-019-03508-6

(C) 2019 The Minerals, Metals \& Materials Society

livilo
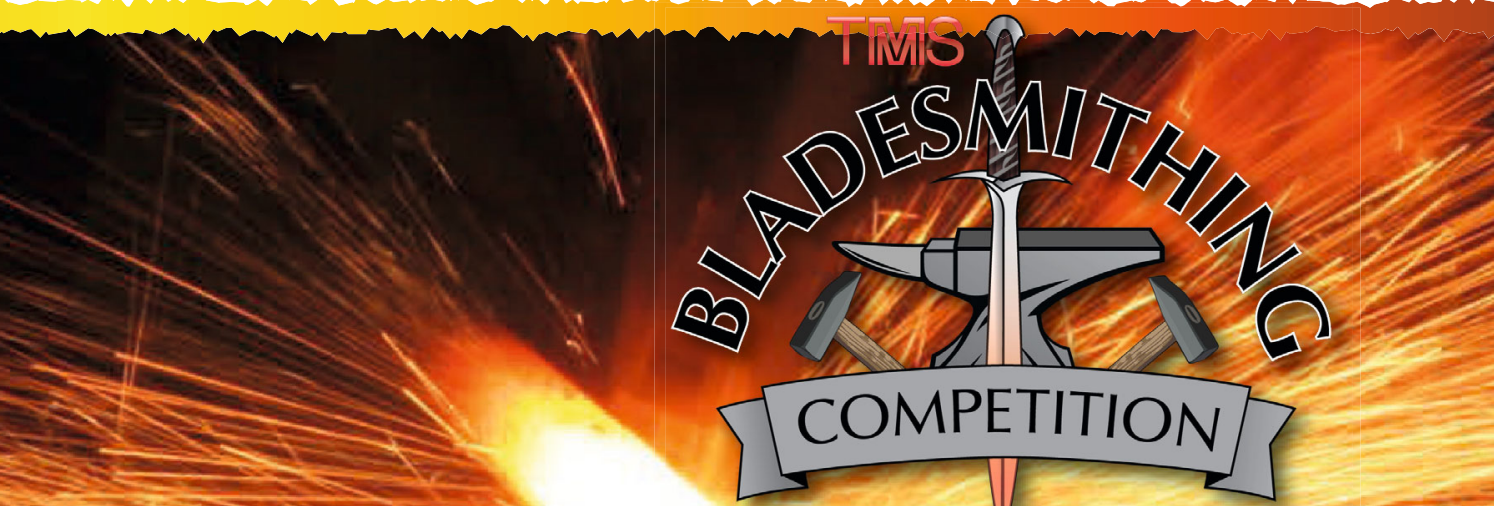

\title{
THE 2019 BLADESMITHING COMPETITION: Where SCIENCE AND CRAFT COME TOGETHER
}

COMPETITION

Ashley-Anne Bohnert

Attendees at the TMS 2019 Annual Meeting \& Exhibition (TMS2019) in San Antonio, Texas, were treated to an extraordinary spectacle of technical skill and craftsmanship as the third iteration of the TMS Bladesmithing Competition showcased 33 forged blades from student teams around the world.

Every two years, university students are challenged to bring metallurgical concepts to life by creating their own blade through hand hammering or trip hammer forging. The competition sparks a passion for the science behind bladesmithing and fires a healthy collaborative spirit among team members. Above all, it is a chance for students to reinforce their materials knowledge while demonstrating their creativity, resourcefulness, and determination.
Completing an entry is no small feat, as noted by 2018 TMS President Kevin Hemker in a speech during the Bladesmithing Awards Ceremony. "The competition marries physical skill and academic rigor as each entry is judged on a cumulative score for the blade, report, poster, and video submissions," Hemker said, praising each student team for rising to the challenge of completing an entry.

Jeffrey Wadsworth, retired president and CEO

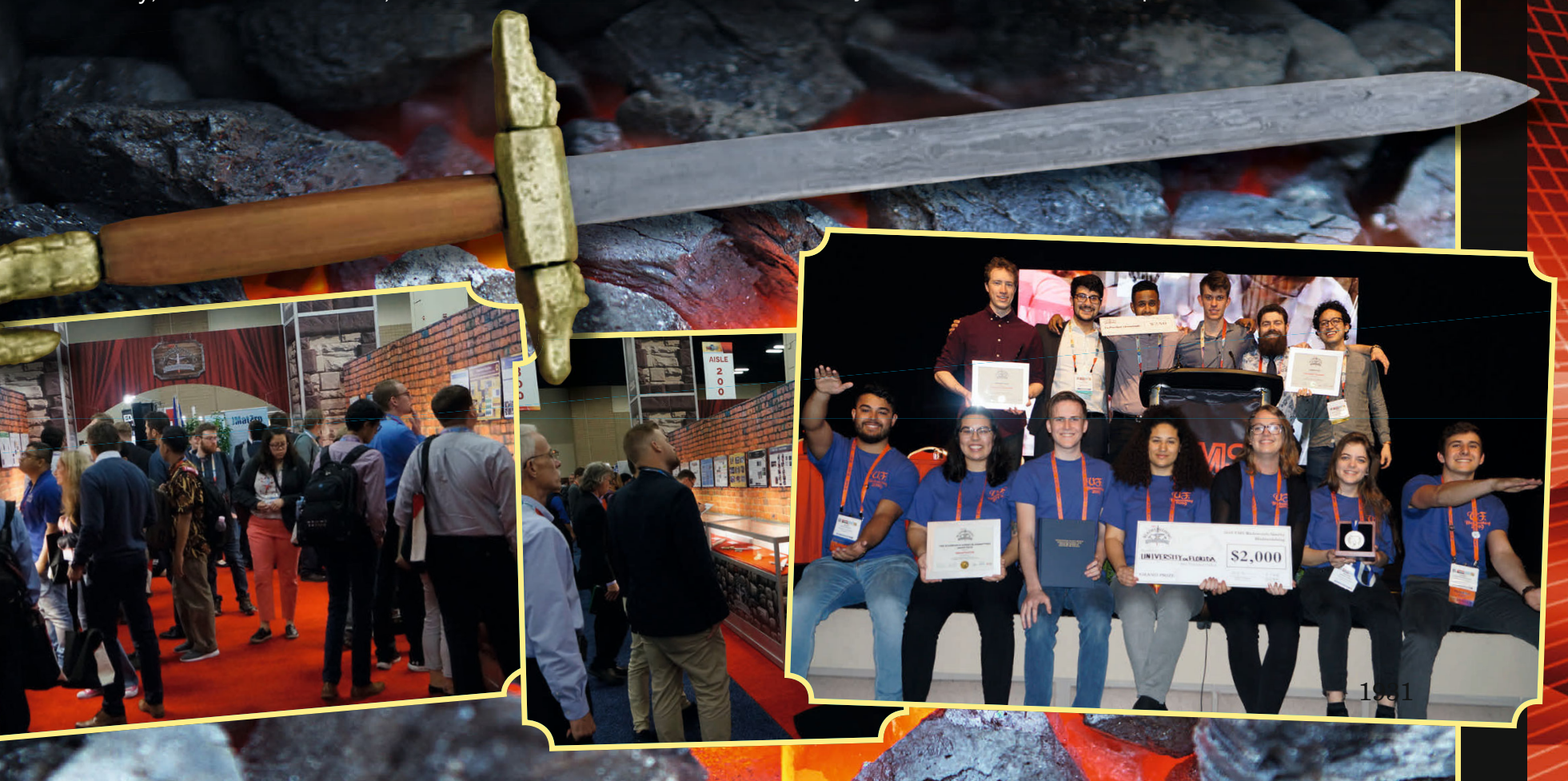


of Battelle, was on hand at the awards ceremony to announce the recipients of the TMS WadsworthSherby Bladesmithing Grand Prize, named in honor of his late mentor, Oleg D. Sherby of Stanford University. This year's competition also included an exciting new highlight: the addition of special citations to acknowledge blades that showed outstanding performance in individual categories such as beauty, hands-on process, or historical accuracy.

In the competition's off years, a Bladesmithing Symposium is held during the TMS Annual Meeting to give past and future contestants a chance to share their experiences and ideas for preparing entries, while also focusing on bladesmithing processes and procedures. Abstracts for the TMS2020 Baldesmithing Symposium are being accepted at www.tms.org/TMS2020. Additionally, new details for the next TMS Bladesmithing Competition, to be held at TMS2021 in Orlando, Florida, will be posted soon. Check the Bladesmithing website at www.tms.org/Bladesmithing for news and updates.

Continue reading this article for a presentation of this year's award and special citation recipients, as well as all 2019 competitors. To find out more about what it takes to complete an entry, you can view team videos at www.YouTube.com/ChannelTMS/Playlists under the Bladesmithing Competition 2019 playlist.

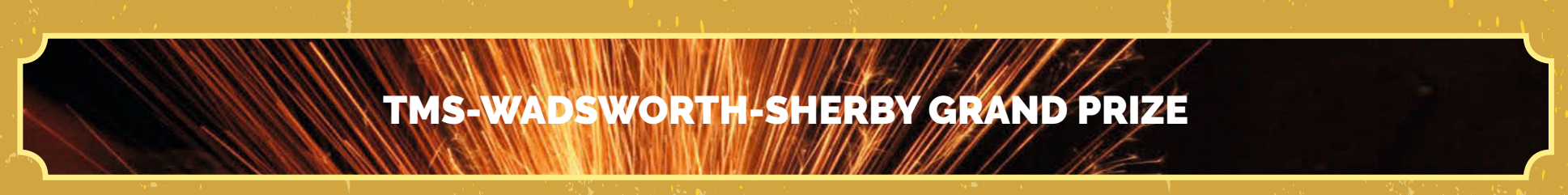

\section{University of Florida: "DECAPIGATOR"}

Award includes \$2,000 Cash Prize, TMS-Wadsworth-Sherby Bladesmithing Grand Prize Medal, and Commemorative Volume of Wadsworth-Sherby Collected Works on Damascus Steels \& Related Topics.

Michelle Thackeray, Alex Aviles, Brandon Capellini, Stephon Dean, Jacob Gusewelle, Evyatar Hashmonay, Jonah Hopton, Emily Huntley, Caroline Kelly, Chris Nacea, Jakub Pepas, Karina Pilo-Ricci, Devin Ritter, Natalie

Starr, Troy Stringfellow, Nicole Trometer, Nadine Ulmer, Mikki Von Schaumburg, and Kellen Wise
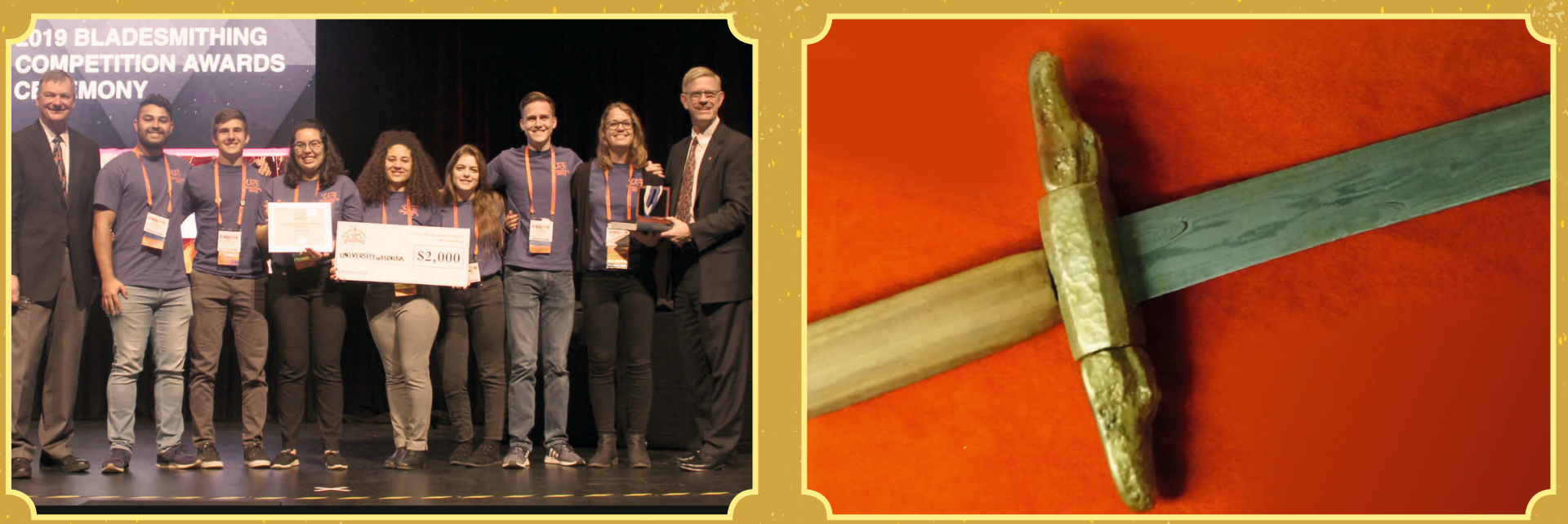

Full-length blade featured on previous page.

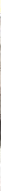




\section{SECOND PLACE}

Colorado School of Mines:

"Rain Drop Pattern Chef Knife"

Award includes $\$ 500$ Cash Prize and Certificate

Stuart Shirley, Itamar Brill, Tyler Mertens, Ty Porter, and Matt Zappulla

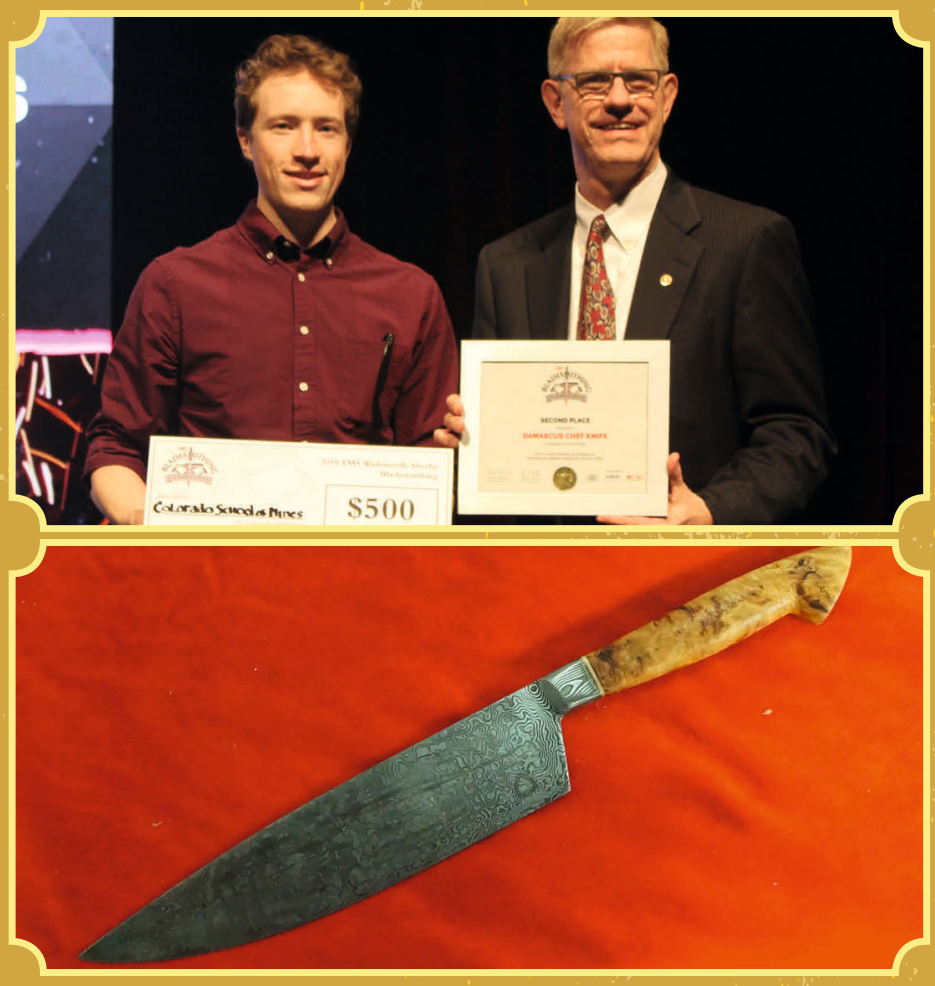

\section{THIRD PLACE}

McMaster University:

"The Mighty Gladius"

Award includes $\$ 250$ Cash Prize and Certificate

Paul Tallon, Yoel Emun, Dan Osoriod, Youssef Salib,

Eric Tenutta, Adam Tyedmers, and Joe Wu

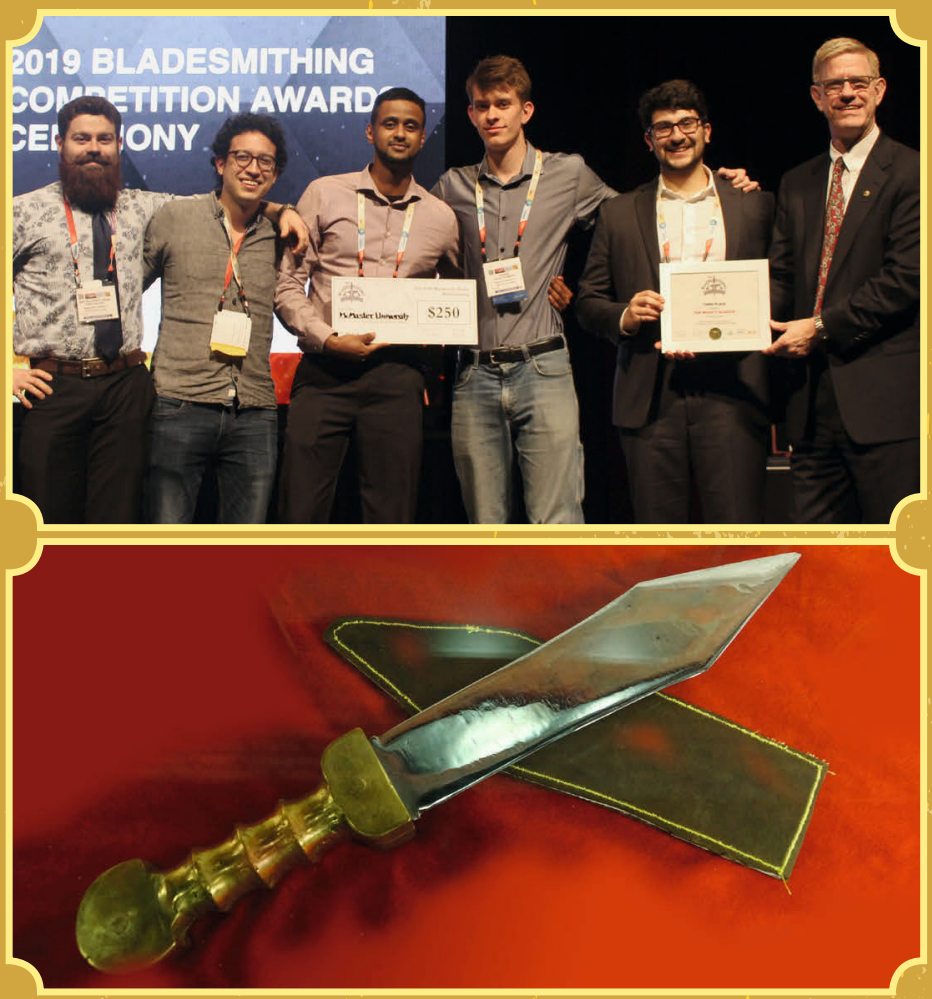

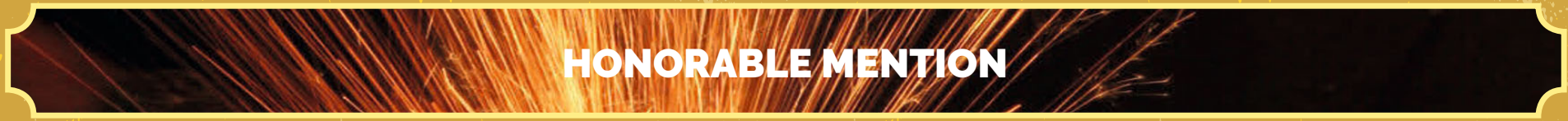

University of Idaho:

"The Fire Creek Forge Bowie Knife"

Award includes $\$ 100$ Cash Prize and Certificate

Brandon Day, Paul Adisa, Mohammed Alqahtani, Vanessa

Beasley, Mark Currier, Jadzia Graves, Arnab Kundu,

Jackson Mitchell, Lily Mortensen, Paul Riebe, Anumat

Sittino, Kendra Wallace, and Elijah Williams
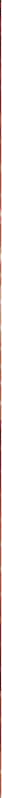


\section{LEARNING FROM AN EXPERT}

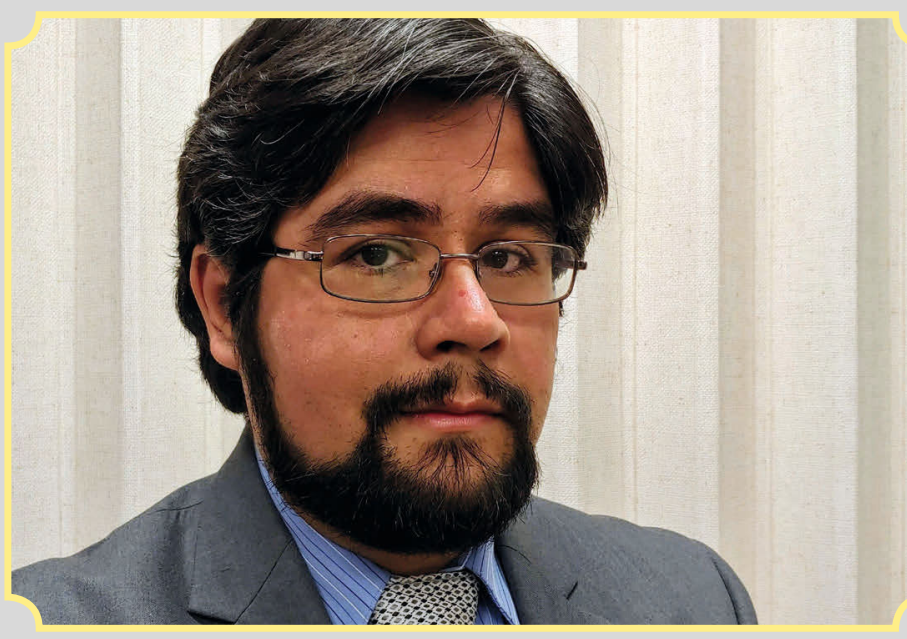

Many of the special citations awarded in the 2019 Bladesmithing Competition were selected by guest judge J. Alex Ruiz, program coordinator of the Wesley Foundation of San Antonio and owner of Volundr Forge. Ruiz is a Texas-based blacksmith and bladesmith best known for his appearance on the popular History Channel series Forged in Fire where he was declared champion for his entry, "The Horseman's Axe."

Since beginning his work as a blacksmith in 2015 Ruiz has taught and demonstrated across Texas. He was also featured in Blade Magazine's 2017 Knifemaker's Showcase. Ruiz currently teaches at the South Texas Assocation of Bladesmiths Headquarters, and is a Lone Star Member of the Texas Knifemakers' Guild and a member of the American Bladesmith Society, the Balcones Forge Central Texas Blacksmiths, and the Artist Blacksmith Association of North America.

Ruiz has dedicated much of his personal and professional life to humanitarian and philanthropic work and his role as a volunteer judge is in many ways an extension of this passion. "I love that it's college students doing this, and I love that an organization is giving its members and students an opportunity to work with their hands," Ruiz noted. "In an age of technology we often dissociate ourselves from menial labor or hand-crafted work...Bladesmithing is a labor-intensive process, even for a professional. It's hot, it's tough, you're going to have blisters like you wouldn't believe, and if you're not paying attention you're going to catch fire."

According to Ruiz, those very challenges are what makes encouraging students to learn crafts such as bladesmithing so invaluable. "Nothing's more humbling than finding faults in your work-but if there's one thing l've learned it's to take notes, not offense," he reflected. "I think that lesson applies to every field. Bladesmithing, or any craft, will teach you not how lacking you are or how good you are, but how much better you can be."

Ruiz's passion for the art of metalworking is evident in conversation. When asked about the challenging process of creating entries for the competition he observed: "They went through all of the trials and tribulations I did when I first started. There's a certain amount of hands-on practice you just have to do to get a product out there that's aesthetically appealing, fully functional, and that someone else is going to want. Looking at these submissions...I see knives that I want in my kitchen, I see blades that I want on my wall, and it's amazing to know that some of these students didn't have a background in bladesmithing before this competition."

And for those interested in learning more about bladesmithing? Ruiz advises them to begin with the fundamentals of blacksmithing by reaching out to local smiths or clubs and, above all, he notes, "Have fun. Learn. Go in with open ears and open eyes. Engross yourself in the culture and history of smithing because there's so much that we wouldn't have today if not for the advancements of metallurgy and blacksmithing working together-science and craft working together."

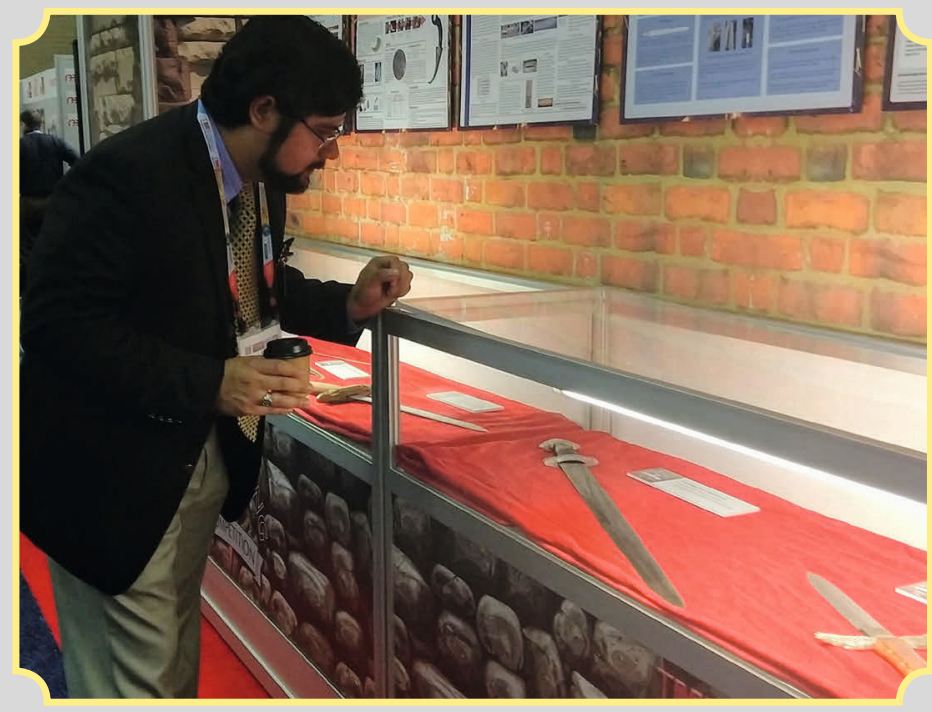

J. Alex Ruiz examines competition entries in the TMS 2019 Bladesmithing Competition exhibit before final judging takes place. 


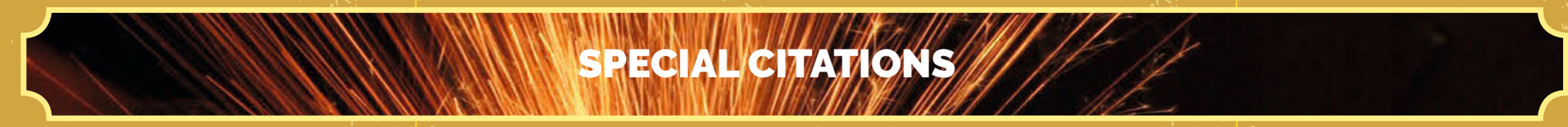

BEAUTY

University of Tennessee, Knoxville: "Volsung"

Cullen Pearson, Scott Bennet, John David Codevilla, Brionna Cooper-Mcmillan, Jonah David Duran, Brandt N. Fox, Mattheus Edward Fry, Gabriel A. Goenaga, Cameron Russell Hale, Eric Heikkenen, Zachary Alexander Herron, Samantha Rose Maness, Joshua James McCoy, Colin Moore, Max Lestat Neveau, Collin Matthew Pekol, Hunter Potter, Craig Thomas Replogle, Bradley Straka, Benjamin S. Terry, Caden Webb, Chris Wetteland, Deshon and Michael Young
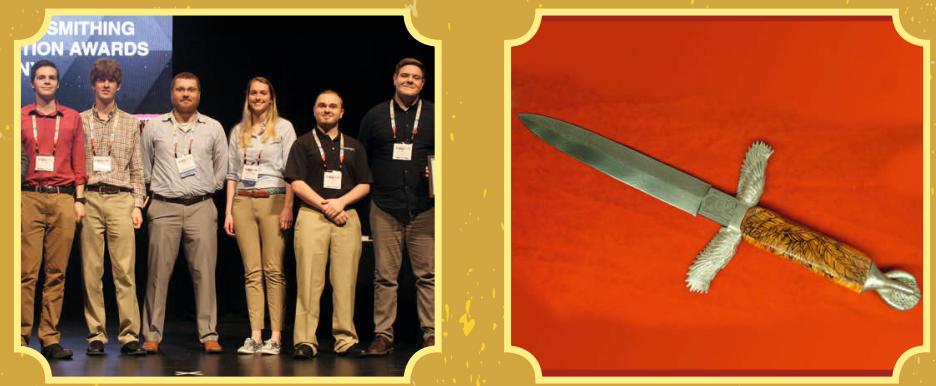

\section{CREATIVE USE OF MATERIALS}

South Dakota School of Mines \& Technology: "Crucible Steel Dagger"

Aaron Fortier, George Bernard, Isaac Hammer, Daniel Nagel, Meghan Strawniak, and Peter Vik
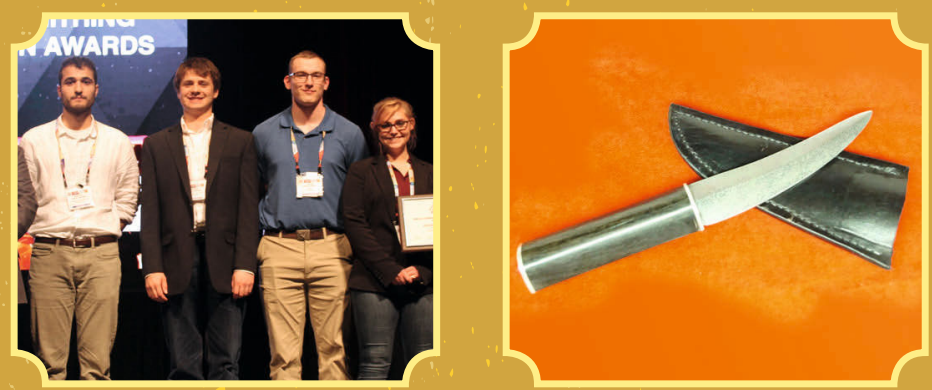

HISTORICAL ACCURACY

Norwegian University of Science and Technology: "T13727 Viking Sword Reproduction"

David Dominikus Eide Brennhaugen, Emilie Bjønnes, Nikolai Skogen Ditlefsen, Inger-Emma Nylund, Erik

Dobloug Roede, Sigurd Grydeland Schawlann, and Tore Andre Søgnen
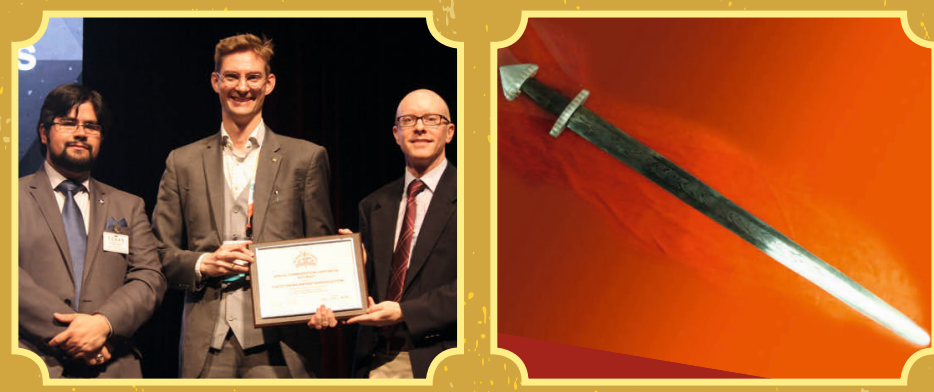

\section{HANDS-ON PROCESS}

Indian Institute of Technology, Bombay:

"Talwar"

Gaurav Raj Singh and Nikhil Gotawala
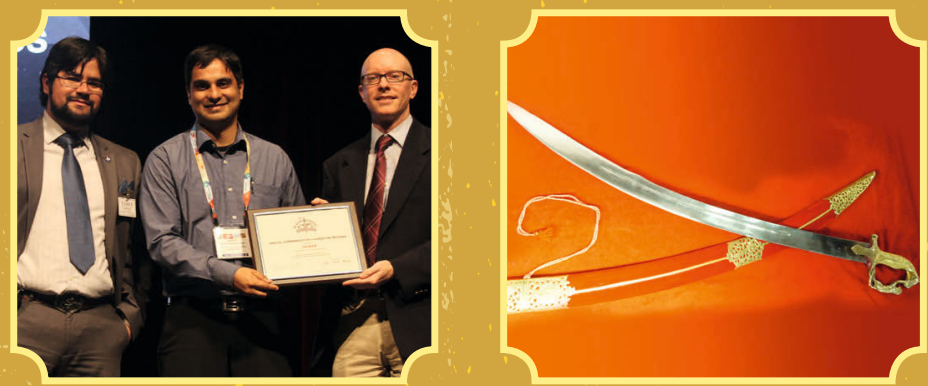

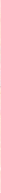




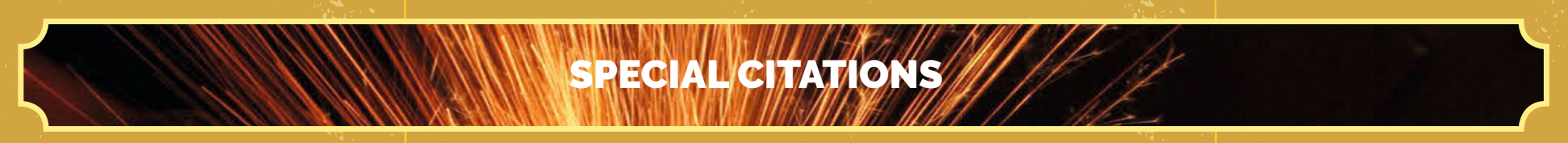

RESOURCEFULNESS

\section{University of Utah:}

"Damascus Steel Swept Rapier"

Jano Farah, Hawken Knight, Olivia Pratt, and Alexander Wikstrom
OUTSTANDINE POSTER

\section{University of Texas at Austin: "Alpha Blade"}

Emily Brady and Katherine Rader
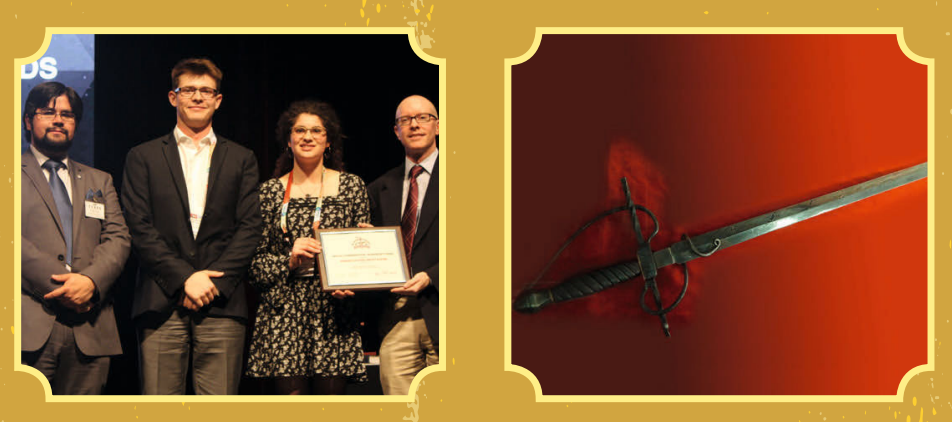
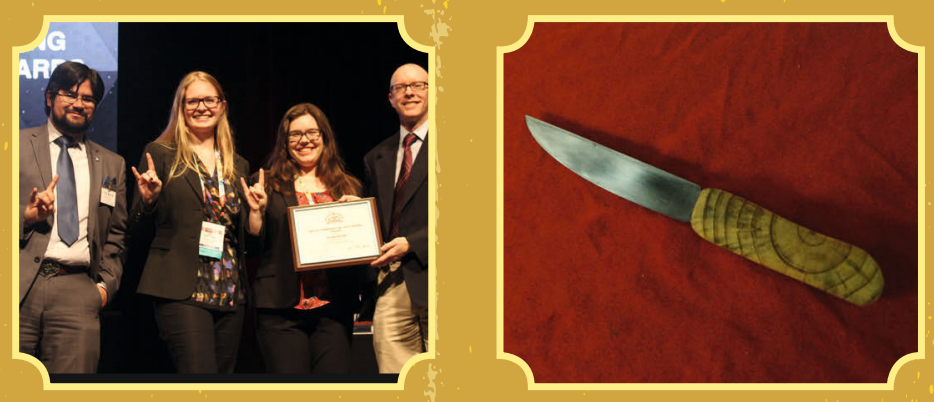

\section{BRINGING BLADESMITHING TO THE CLASSROOM}

From its inception in 2015, the TMS Bladesmithing Competition has sparked excitement among participants. Gerald Bourne, professor of metallurgical and materials engineering at Colorado School of Mines (Mines), channeled that excitement into a bladesmithing course, photo left, that complements the university president's focus on "creating unique and hands-on student experiences at Mines."

The class, created by Bourne and students Ty Porter, Stuart Shirley, and Matt Zappulla, takes a safetyfirst approach, both in terms of lab equipment and common sense in handling edged tools. It also covers concepts such as profiling, bevel grinding, heat treating, sharpening, and ferrous metallurgy focused mostly on tool steels for knife making.

The course has been an incredible success filling each semester with students from multiple departments. I hear students who are not in our department and who I have never met discussing the course," noted Bourne. "Once enrolled in the course, excitement is a very significant motivator. Students go above and beyond expectations on their projects. I also feel the creative outlet gives the students a break from studying, and they are proud of the work that they put into the projects and the final outcome."

Students from Virginia Polytechnic Institute and State University (Virginia Tech), photo right, have found an
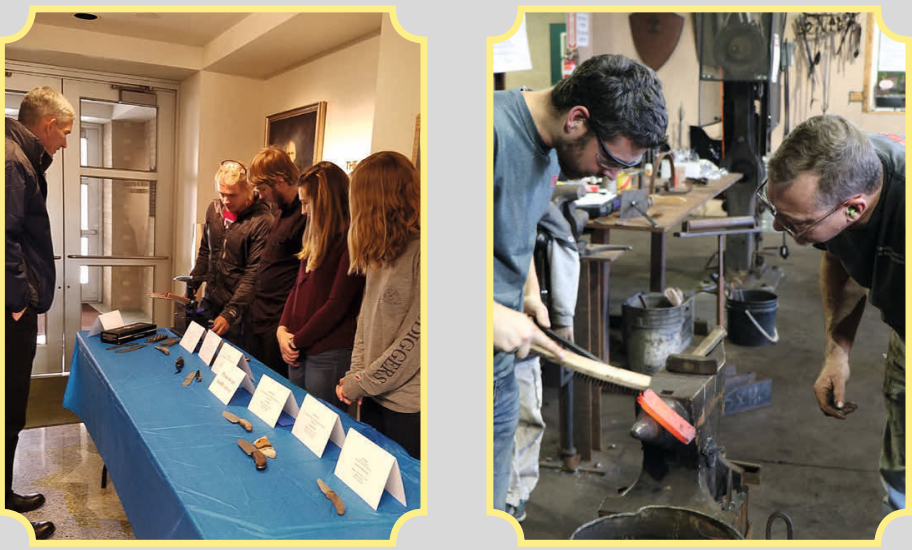

ingenious way to provide a safe outlet for forging on campus by offering the first ever bladesmithing class in 2020. Developing a formal class gives students the opportunity to practice bladesmithing within the context of a syllabus that covers a basic introduction to forging science and techniques.

Harrison Jones, bladesmithing team lead at Virginia Tech, credited the TMS Bladesmithing Competition with introducing the majority of his team to the art of forging. "The spur of interest in this type of material processing through our department prompted students and faculty to work together to provide an outlet for the general student body to learn more." According to Jones, "the students benefit from the hands-on experience of physically working on the metal and conducting research into the material's properties. Being able to see the results of our work reinforces what we're learning in the classroom." 


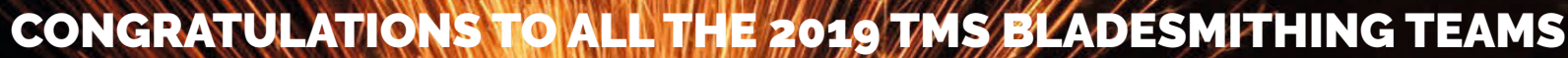

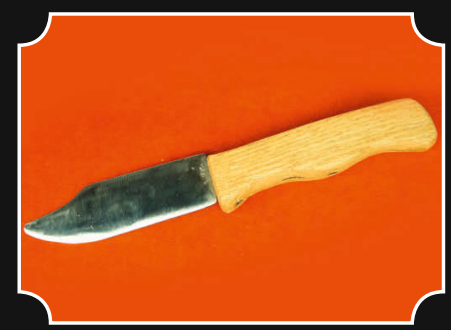

Drexel University

"Occam's Razor"

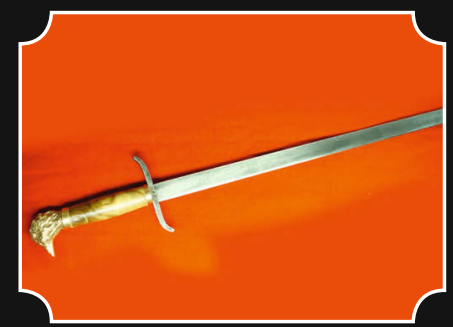

Friederich-Schiller-

University Jena

"Hugin"

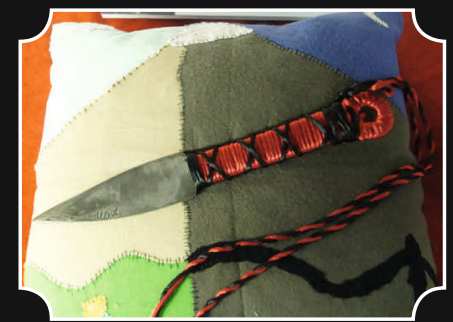

Illinois Institute of

Technology, Armour

College of Engineering

"Kunai"

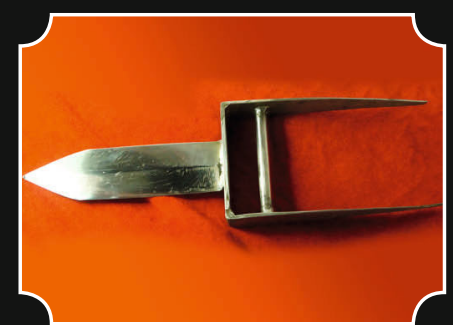

Indian Institute of

Technology, Madras

"Indian Wootz"

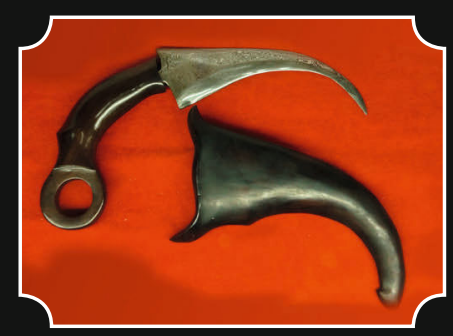

Institut Teknologi Sepuluh Nopember

"The Karambit,

Indigenous Martial Arts

Weapon of Indonesia"

Michigan State University

"An Agricultural Tool, and Then Some"
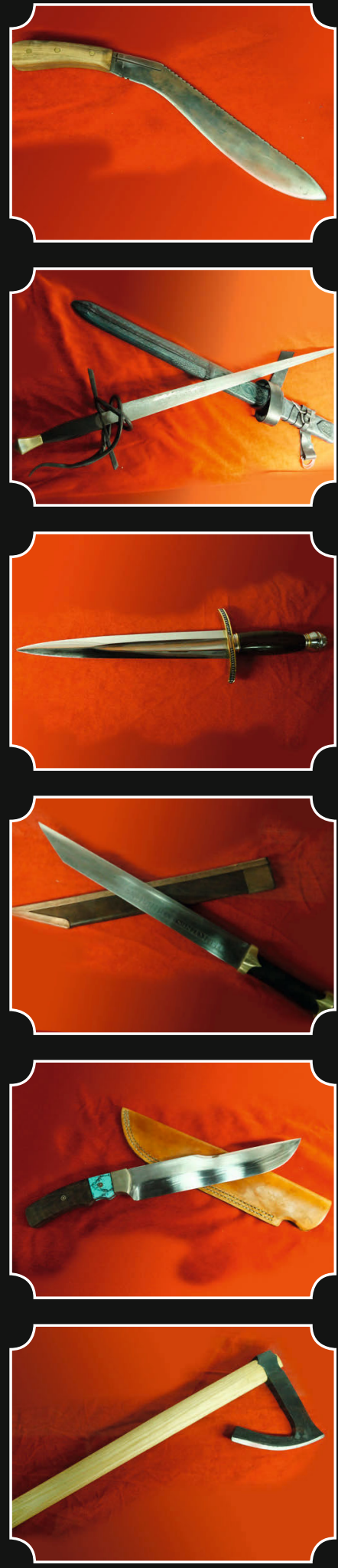

Michigan Technological

University:

"MTU Kukri"

Missouri University of

Science and Technology:

"Stahlzahn"

Montana Technological

University:

"Renaissance Dagger"

Montanuniversität Leoben:

"Historically Inspired Broken Back Seax"

New Mexico Institute of Mining and Technology:

"Second Heat"

Oregon Institute of

Technology:

"Viking's Little Helper" 


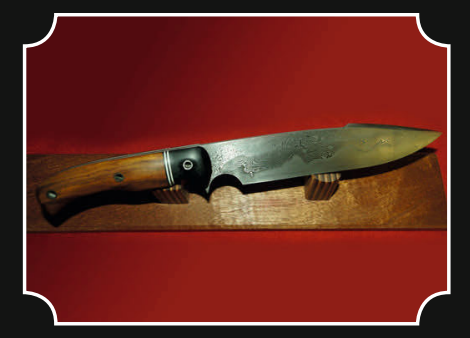

Oregon State University:

"Raindrop San Mai

Damascus Bowie"

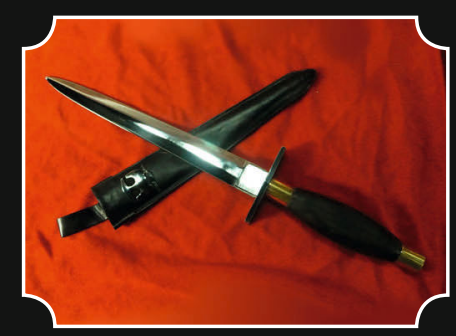

Universidad Nacional Autónoma de México:

"Iztactepostli"

Universidad San Francisco de Quito:

"Dragon Dagger"

University of Alberta:

"Double-edged Sword"

University of California, Berkeley:

"Ax L. Rose"
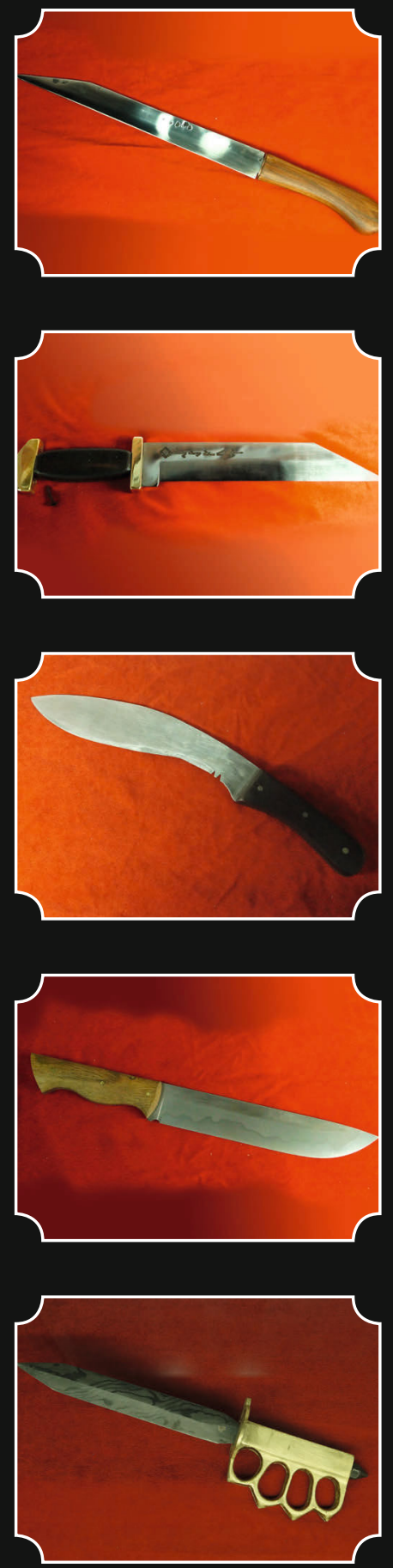

University of Minnesota

Twin-Cities:

"Seax Blade"

University of North Texas:

"Anglo-Saxon BrokenBack Seax"

University of Pittsburgh,

Team \#1:

"PittSmiths"

University of Pittsburgh,

Team \#2:

"It's a Wonderful Knife"

Virginia Polytechnic Institute and State

University:

"World War I Trench Knife Replica"

University of California,

Irvine:

"Utilitarian Kitchen

Chopper" 